\title{
Knowledge Management System and Financial Performance: how this relation has been measured?
}

Fabiana Dutra de Campos Souza

Master's Degree in Information Systems from Fumec. Financial management specialist from Fundanção Dom Cabral Graduated in Business Administration from the PUC-MG It is technical in computer science from CEFET - MG and has experience in project management, process management and management consulting

Djan Magalhães Castro

Djan hold positions as Business Intelligence and Commercial coordinator in automotive company. He received a Master Degree in Information Systems from the FUMEC. Business management specialist from the FGV Graduated in Computer Science from the PUC-MG

Fabricio Ziviani

PhD in Information Science from the UFMG (2012), Master's Degree in Public Management from João Pinheiro (2005). Professor at FUMEC, FDC University, Brazil. Executive member of INOVATECX Soluções Corporativas LTDA

Fernando Silva Parreiras

Professor at FUMEC University, Brazil, leading the Laboratory of Advanced Information Systems (LAIS). Received a PhD in Computer Science from the University of Koblenz Landau, Germany, summa cum laude, supervised by Prof. Steffen Staab. Prior to joining the FUMEC University, I held positions as researcher and project leader at the University of Koblenz Landau and as software developer at Unisys

http://dx.doi.org/10.1590/1981-5344/2632

This paper compiles the latest knowledge management $(K M)$ studies that had financial performance correlated in the last years, shows main financial indicators used and provides insights and rich context to deepen evaluation. The method adopted was a Systematic Literature Review (SLR) on studies published from 2009 to May 2015. Many 
topics were analised in the selected papers of this research. Firstly, KM practices found were categorized according to Ho (2009). Secondly, the financial indicators used were compared to indicators identified by Combs; Crook; Shook (2005). Thirdly, the most frequently measures used in the relationship between KM practices and financial performance were identified. Finally, we highlighted the most used methods to evaluate impact of $K M$ in FP, evaluation of number of Publications per year and evaluation of Authors, Publishers. The paper finds that in despite of increasing number of publications correlating both topics the effects of $K M$ in financial performance has to be more explored. However, majority of paper reports certain improvement in financial performance of companies that strongly support KM.

Keywords: Knowledge Management; Knowledge Management System; Financial Performance; Systematic Review; Bibliometry.

\section{Sistema de Gestão do Conhecimento e Desempenho Financeiro : como esta Relação foi medido}

Este documento compila os mais recentes estudos de Gestão do Conhecimento (GC) que tiveram desempenho financeiro (DF) correlacionados nos últimos anos, mostra os principais indicadores financeiros utilizados e fornece insights e rico contexto para aprofundar a avaliação. 0 método adotado foi uma revisão sistemática da literatura (RSL) em estudos publicados de 2009 a maio de 2015. Muitos tópicos foram analisados nos trabalhos selecionados nesta pesquisa. Em primeiro lugar, as práticas de GC encontrados foram classificados de acordo com Ho (2009). Em segundo lugar, os indicadores financeiros utilizados foram comparados com indicadores identificados por Combs; Crook; Shook (2005). Em terceiro lugar, medidas mais freqüentemente utilizadas na relação entre as práticas de GC e desempenho financeiro foram identificadas. Finalmente, foram destacados os métodos mais utilizados para avaliar o impacto da GC em FP, realizada a avaliação do número de publicações por ano e a avaliação de Autores, editores. O documento conclui que, apesar de o aumento do número de publicações correlacionando os dois temas, os efeitos da 
GC no desempenho financeiro têm de ser mais explorados. No entanto, a maioria dos trabalhos relata certa melhoria no desempenho financeiro das empresas que apoiam fortemente GC.

Palavras-chave: Gestão do Conhecimento; Sistemas de Gestão do Conhecimento; Desempenho Financeiro; Revisão Sistemática de Literatura; Bibliometria.

Recebido em 24.11.2015 Aceito em 26.04.2016

\section{Introduction}

Acceleration in the rate of technology development shaped the current business environment (DAVENPORT; PRUSAK, 1998). Due to complexity of organizations and the markets in which companies compete in order to continue sustainable, organizations have had to focus on Knowledge Management (KM) as a solution to enhance process and create innovation. There seems to be little doubt that nowadays, KM is extremely critical to the smooth and successful operation of most organizations (HOLSAPPLE; WU, 2011). Knowledge should be considered the most valuable competitive assets, instead of machinery and equipment for firms (DAVENPORT; PRUSAk, 1998).

Joshi, Chawla \& Farooquie (2014) believes that the most important reasons for the emergence of knowledge economy are globalization, need for innovation and differentiation, proliferation of technology and changing stakeholders expectations. Both Internet and mobile connectivity have made a significant contribution to globalization. Besides, there is a far greater awareness of opportunities that has resulted in high employee turnover and perennial loss of knowledge.

The traditional approaches to performance measurement have been on financial measures only. However, by the late 1980s, studies had shown that historic financial measures are not sufficient enough to understand the performance management in the new economy because of the increasing complexity of organizations and the markets in which companies compete (NEELY, 2002). Kaplan \& Norton (1996), with BSC show us the requirement to use a more holistic perspective of performance and measurement including financial performance, customer knowledge, internal business processes, and learning and growth. Kaplan and Norton argued that managers should not only concentrate on financial measures when taking decisions. Tabrizi, Ebrahimi \& Al-Marwai (2011) argued that the nature of knowledge economy compels organizations to light on new performance indicators to move nimbly.

Definitely the knowledge economy had shown that historical financial measures are not enough to understand the performance management when shortened product life cycles and hyper rivalry are constant(Neely, 2002). However, one common drawback is the linkage 
between KM and organizational Performance Measurement (PM). Unlike financial performance, which is characterized in terms of standard accounting measures, there are no standard means for measuring ingredients that underlie KM performance. (HOLSAPPLE; WU, 2011). Despite the various studies trying to develop metrics and methods to measure knowledge, continue to be one of the most difficult parts of the knowledge management (KM) activities (CHEN; HUANG; CHENG, 2009). Linking KM practices to business results and competiveness is not easy and there are disparate views among researchers (JOSHI et al., 2014).

Once civilization entered the knowledge era, the resource-based view of the firm, as a relevant conceptual framework for understanding strategic management, gained a new dimension in the knowledge-based theory of the firm in which knowledge is seen as a strategic asset of an organization that needs to be managed. Knowledge management means identifying, developing and leveraging knowledge across the organization with the purpose of achieving competitive advantage (SLAVKOVIĆ; BABIĆ, 2013). According to the resource-based theory (RBT), the main driver of firm performance is a set of unique firm resources that are valuable, rare, difficult to imitate, and non-substitutable by other resources (HOLSAPPLE; WU, 2011). Many strategists have considered knowledge resources as the primary capital rather than the traditional capital, such as land, equipment and raw material, for being the most important input of an organization's value creation process. This concept mainly builds upon an extension of the RBV, the knowledge-based view and has well shown its importance in the knowledge economy (M.-Y. Chen et al., 2009). Changes to organization practices in general, and $\mathrm{KM}$ in particular, do not necessarily result in changes to financial performance (HEDMAN; KALLING, 2003).

Here, we report a compilation of articles written since 2009 untill May 2015 about KM and Financial Performance (FP), in order to contribute to identify the main influential factors in $\mathrm{KM}$ according to authors and their respective influence in FP.

This paper has been organized as follows: in Section 1, the purpose of this paper is detailed. In Section 2 the related literature is reviewed and related work identified. The details of methodology are in Section 3. Next, in Section 4, results are presented. Then, in Section 5, we conclude this paper with suggestions and future researches.

\section{Background and related work}

M.-Y. Chen \& Chen (2006) developed a literature review and classification of articles from 1995 to 2004, in order to explore KM performance evaluation during that period. The history of KM evolution, over the past decade, can be seen: 
Figure 1 - The history of KM evolution

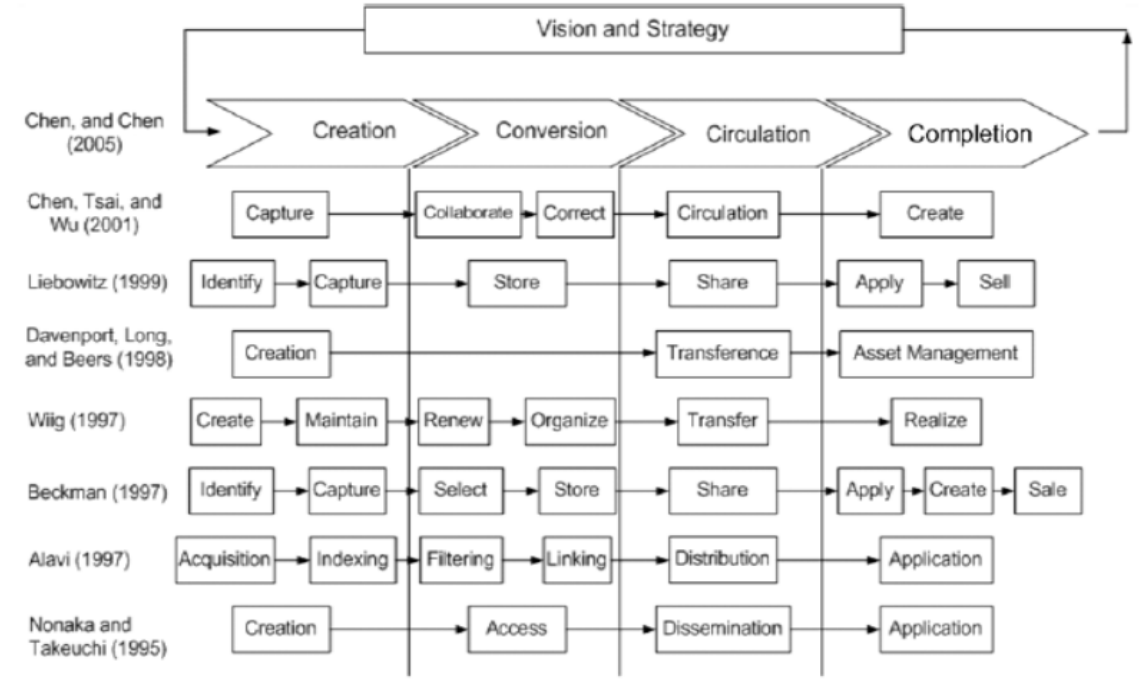

Font: CHEN \& CHEN (2006).

M.-Y. Chen \& Chen (2006) surveyed and classified methods of KM measurement, using the following eight categories: qualitative analysis, quantitative analysis, financial indicator analysis, non-financial indicator analysis, internal performance analysis, external performance analysis, project-orientated analysis and organization orientated analysis, together with their measurement matrices for different research and problem domains. According to this study, the number of research grew from 2000 to 2004 and quantitative is greater than the others.

Figure 2 - Articles classified on measurement categories by M.-Y. Chen \& Chen (2006)

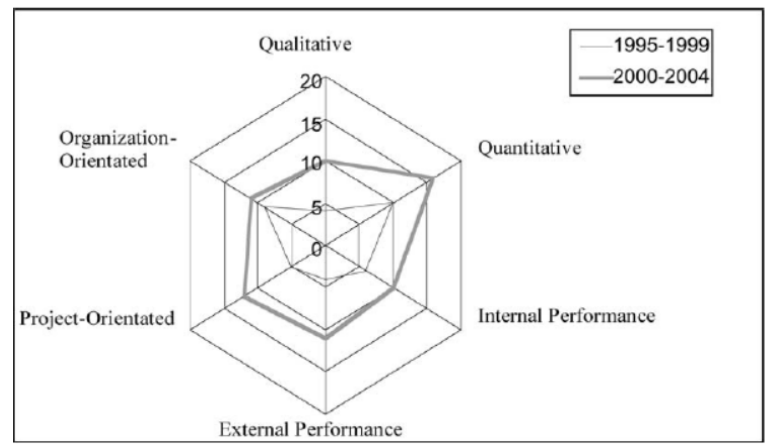

Font: CHEN \& CHEN (2006, p. 16).

The basic underlying assumption is that knowledge may be viewed from a unified perspective; it circulates in the organization creating knowledge assets and influences the performance of the organization. It has multifaceted characteristics, such as: state of mind, object, having access to information, or the potential for influencing future action.

Clyde W. Holsapple, Jiming Wu b (2011) presents a prior relevant KM studies and explaIn: first, it appears that KM performance is an important factor for managers to consider. Second, many of the studies 
show a positive relationship between some aspect(s) of KM performance and some aspect(s) of firm performance. Third, most of the empirical findings are based on perceptions of independent and dependent variables by persons embedded in the firms being studied. This type of research adds risks, complications, and inefficiencies for initiatives involving knowledge creation, knowledge retention, and knowledge transfer, Fourth, few studies examine whether a firm's actual financial performance is related to its $\mathrm{KM}$ performance.

Similarly, the cost/benefit of investment in KM systems has been a question for a long time after some of the initial installations of big, expensive IT structures were disappointing. That consideration, along with concerns that spreading knowledge too widely might lead to greater vulnerability to competitive intelligence or other incursions by competitors, suggested that a more measured approach to sharing proprietary knowledge assets might be more prudent (ERICKSON; ROTHBERG, 2015).

Cohen \& Olsen, (2015) reveals that codification and human capital KM capabilities interact to influence customer service outcomes. Links between KM capabilities and performance were found to be contingent on the business strategy of the firm.

Researchers have devoted much attention to empirical examination of the link between knowledge management (KM) and firm performance. Efforts have typically concentrated on the KM capabilities required for the externalization and codification of organizational knowledge, and for the development and retention of tacit knowledge embedded in human capital. Competing theoretical perspectives regarding the interrelationship between these two KM capabilities and their implications for performance in the past researches. The effects of KM capabilities on the performance of firms in service sectors such as hospitality has received less attention.(COHEN; OLSEN, 2015)

Different constructs have been associated with organizational performance, with different levels of relevance. Yang et al., (2009) shows that organizational structure and knowledge management culture are associated with organizational performance such as innovativeness, finance, and customer service. For those authors, information technology didn't support affects financial and customer service in shipping firms. It was noted that the shipping executives preferred to depend on their own experiences and networking relationships. Thus, a trust-based culture is the foundation for their knowledge management initiative. However, this research was limited to an evaluation of the knowledge management enablers and firm performance in liner shipping firms.

D.-N. Chen \& Liang (2011) defends that more and more organizations are taking advantage of external knowledge sources such as online communities (e.g., blogs and social networking websites) to enhance their competitiveness and that Knowledge could become an intangible product to be traded in electronic commerce. Their results show that different knowledge evolution strategies have affected different dimensions of organizational performance. Knowledge mutation that relies 
on internal creation of new knowledge has significant impacts on the improvement of internal process, while knowledge crossover that takes advantage of external knowledge sources can benefit financial and customer dimensions. It implies that when the goal of knowledge management is to improve business processes, internal innovation may be better than seeking advice from outside sources, but when the goal is to improve customer satisfaction and retention, bringing in outside expertise will be better than relying on internal knowledge. In addition, many industrial factors, such as environment variation, knowledge density, and organizational factors, including IT capability and sharing culture, are found to have moderating effects. The findings of this research will help organizations choose the right strategy for knowledge enhancement and light up new directions for further research.

According to Erickson \& Rothberg, (2009, p. 159), both IC (Intellectual Capital) and KM concern themselves with identifying and better leveraging the knowledge assets of the organization but also differ somewhat in emphasis and application. KM tends to be more human resources oriented, including both the big IT systems necessary to collect, store, and distribute codified knowledge and more person-to-person applications such as communities of practice, storytelling, wikis, and related techniques. $\mathrm{KM}$ also tends to focus more on the details of the nature of the knowledge (e.g. tacit vs. explicit) and the motivational issues involved in getting individuals to participate in knowledge-sharing systems. IC, on the other hand, grew more out of accounting, trying to tease out the components of the intangible assets that have become so prominent in recent decades. If you can measure specific intangibles, especially those we would consider knowledge assets, we can better manage them. As the metrics and understanding get more precise, our ability to manage human capital, structural capital, and relational capital improves.

$\mathrm{KM}$ is an interactive process and starts with a business driver or vision of what a company wants to achieve. For effective $\mathrm{KM}$ implementation, organizations need to create and manage processes and systems to capture and apply knowledge sources from internal and external stakeholders. Earlier researchers have identified many key aspects in the $\mathrm{KM}$ processes such as acquiring, collaborating, integrating and experimenting knowledge acquisition, knowledge conversion into useful form, application and protection; acquisition, indexing, filtering, linking, distributing and application; and knowledge acquisition, knowledge sharing and knowledge distribution. Managing knowledge in organizations requires managing several processes of knowledge such as initiation, implementation, ramp-up and integration; generation (acquisition; dedicating resources; fusion; adaptation; and building knowledge networks), codification and transfer; acquisition, conversion, application and protection; acquiring, selecting, internalizing and using; acquisition, selection, generalization, assimilation and emission; creation, transfer, integration and leverage, creation, storage, sharing and 
evaluation ; generation, codification, transfer and; and acquisition, creation, storage and application (JOSHI et al., 2014).

KM practices, in this research, are defined according to Zack, McKeen, \& Singh (2009) as observable organizational activities that are related to knowledge management. Four key dimensions of KM practice were identified from them to relate to performance: a) the ability to locate and share existing knowledge; b) the ability to experiment and create new knowledge; c) a culture that encourages knowledge creation and sharing; and d) a regard for the strategic value of knowledge and learning.

Zand, van Beers, \& others (2010, p. 3) explain that exists 2 different approaches in the literature that analyze the impacts of enterprise systems in the firm performance. The first group treats supply chain management (SCM), customer relationship management (CRM) and knowledge management system (KMS) concepts as a corporate policy, management practice or organizational capability. The second group explicitly focuses on SCM, CRM, and/or KMS as IT-based enterprise systems. At this research, KMS will be considered like first group.

The objective of a Knowledge Management System (KMS) is to support construction, sharing and application of knowledge in organizations. "The strategy of utilizing a KMS to capture and distribute knowledge often requires that individuals contribute their knowledge to a system instead of keeping it to themselves or sharing it directly with known others only through conversations or written personal exchanges" (ALAVI; LEIDNER, 2001, p. 1). According to Wang et al. (2008), the better a firm is at KM, the more competitive it will be in the market and the better its performance.

Performance and performance measurement are complex constructs. To Neely, Gregory, \& Platts ( 2005), "performance measurement is a topic which is often discussed but rarely defined. Literally it is the process of quantifying action, where measurement is the process of quantification and action leads to performance". According to (BANFF; BAPUJI, 2006), several scholars have recognized the multidimensional nature of performance and viewed it as comprising (i) goal attainment, behavior of organizational participants, and relationship with environment, (ii) efficiency, employee morale, and effectiveness in meeting goals, (iii) financial performance, operational performance, and organizational effectiveness, and (iv) adaptive specialization and adaptive generalization.

Combs; Crook; Shook (2005) describes that there is a wide variety of available alternatives to classify the dimensions of performance and divides the performance measures into two main and distinct groups: operational and organizational performance. A measure is coded as operational if could be tied to a specific value chain as described by Porter but did not reflect the interactive outcome of all value chain activities. Measures that depict outcomes attributable to the interaction among all value creation activities and the organization's environment, were treated as organizational performance measures. 
In our research, we consider the categories by Combs; Crook; Shook (2005) to treat financial performance and the categories proposed by $\mathrm{Ho}(\mathrm{HO}, 2009)$ in article to treat KM constructs of KM Process and KM Enablers both compiled by Andersen (1999).

\section{Research methodology}

This research was conducted like a systematic review divided in two major steps. First, a Bibliometric Study was conducted to understand the universe around this theme. After that, papers were reviewed to understand how the literature has connected Knowledge Management Systems and Financial Performance in an organizational level and identify the mainly KM practices and financial performance indicators.

This research was carried out based on the guidelines presented by Kitchenham (2004). The procedure of systematic review includes the following steps: planning, defining research questions, searching databases, discussion of validity, data extraction, and synthesis of the results. These steps are described in the next subsections. Two researchers were involved in this research, and they are the authors of this paper. From here on, the term "authors" is used as researchers.

\subsection{Planning}

The goal of systematic review is to find out how the authors have, in the literature, linked KM practices and financial performance in an organizational level of firms. A review protocol was developed in the beginning of the systematic review to make sure that the research is undertaken as planned and not driven by researcher expectations. The protocol includes research background, the research questions, search strategy, study selection criteria and procedures, quality assessment, data extraction, and data synthesis strategies. The research questions and article identification strategies are described in the following subsections.

\subsection{Research questions}

This research seeks to answer the following questions:

a)RQ1: What researches has been conducted and reported to link KMS and financial performance?

b)RQ2: What are the main KM practices treated on the studies that measure relationship between $\mathrm{KM}$ and financial performance?

c)RQ3: What are the main financial indicators used in reviewed papers for evaluating $\mathrm{KM}$ outcomes from financial perspective?

The main objective of RQ1 is to understand how this topics are being correlated over last six years. We tried to understand who are the 
authors, which are the publishers that usually publish more and what are the most frequent words related to these papers. This dataset was analyzed using Lotka (1926) and Zipf laws. The purpose of RQ2 is to identify the main KM practices that had been linked with financial performance. Finally, RQ3 gets a whole picture of financial indicators that had been more cited in the selected papers. In order to group these indicators, we use categories proposed by Combs; Crook; Shook (2005).

\subsection{Research strategy and search process}

\subsubsection{Search resources}

This study was planned to find relevant literature about the link between KMS and financial performance in the last years. Based on the fact that $\mathrm{KM}$ is a multidisciplinary topic, we search in two different electronic databases: SCOPUS and Science Direct. In the searches, were used the same research string. It was considered only papers and conferences. The results of these researches were 226 results from SCOPUS and 187 from Science Direct, totalizing 413 results. Manually researches were conducted from list references and result in one significant paper.

\subsubsection{Search process}

After some tried searches, the following search string was decided on for this study: ("knowledge management system" + "financial performance").

The search string try to filter papers that treat KM systems and financial performance in the same time. It was used on the electronic databases on 28 June 2015. It was filtered only papers and conference papers and it was returned 413 researches. One more was manually added. After duplicate papers were removed by Zotero tool, 371 papers remained. After Zotero analysis, authors identified four repeated articles more, resulting in 367 unique papers. After removing the papers that are out of the inclusion criteria, 44 papers remained to be analyzed. The analyses and conclusions about the final selected papers were conducted by both authors, together. Inclusion and exclusion criteria are explained bellow.

\subsubsection{Inclusion and exclusion criteria} criteria:

The paper is kept in the study if it satisfies all of the inclusion

a) Academic papers published on journals or conferences;

b)Publication period: 2009 till May 2015;

c) Papers related to KMS and financial performance, at same time; 
d)Papers that have treated KMS concept as a corporate policy, management practice or organizational capability.

e) Papers that have explicited on it, which KM practices were used on research;

f)Papers that have explicited on it, which financial performance indicators were used on research.

The paper is kept out if it satisfies any of the exclusion criteria:

a) Duplicate papers found on the digital libraries.

b)Books, thesis, editorials, prefaces, article summaries, interviews, news, reviews, correspondence, discussions, comments, reader's letters and summaries of tutorials, workshops, panels, and poster session;

c)Studies published out of period between 2009 and May 2015;

d)Studies that explicitly focuses on KMS as IT-based enterprise systems;

e) Studies that are only available as abstracts.

\subsection{Classification validity}

The goal of this study is to cover, as many as possible, the relevant research papers about the link between KMS and financial performance and put them into categories to make possible having a quantitative view about use of KM practices and performance indicators. Nevertheless, it is likely that some relevant papers have been missed. This can be attributed to a number of different reasons. First, even in the English language, there is some ambiguity. This means that some relevant papers that use a different terminology of the search string might not have been found. Second, some lesser-known journals and proceedings are not included in the electronic databases that were searched, and any possible papers published in these collections were therefore not included in the results. Next, some papers can also have been rejected incorrectly during the selection process from the search results to the final list of relevant papers.

Figure 2 - steps by research process of this work 


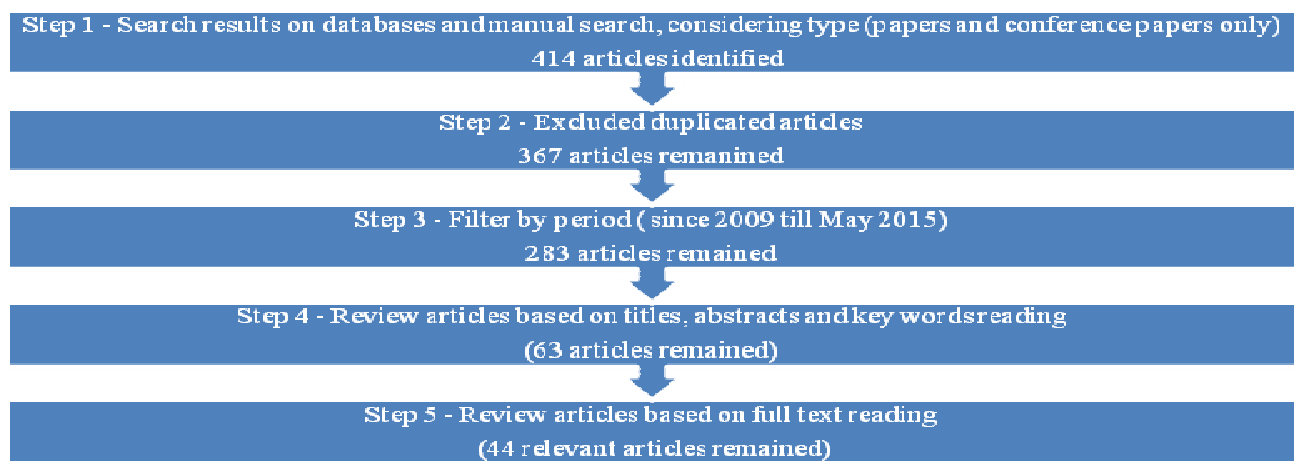

The following measures have been taken to improve the validity of the research and to minimize the number of missed papers:

a)The inclusion and exclusion criteria at every step were explicitly defined and agreed upon by all authors. This makes the results from different authors more consistent and objective.

b)For the selection based on articles based on titles, abstracts and key words, the following steps were conducted:

first, one author were classified all relevant papers in "Exclusion yes", "Exclusion no" or "Maybe", considering the inclusion criteria and exclusion criteria;

- after this author classified all relevant papers, the other author rechecked the rejected papers and further added any papers that they considered as possibly relevant;

- then, all the papers in which there were doubt or not consensus between the authors were argued till the consensus.

- the main reasons to eliminate the paper at this step was focus on no financial performance and KMS out our concept (focused on IT and not in KM practices).

a)At any time when one author was not certain about the decision, the other author looked at that particular paper, and the final classification was decided when all authors agreed on it.

b) To further complete the list of relevant papers, the most cited papers at reference lists were searched. This resulted in the identification of an extra one relevant paper (ZACK et al., 2009) that had not been included in the list before.

We choose carefully the inclusion and exclusion criteria and worked with many communication to guarantee align between the authors. For example, if the measured used in research was not explicit, the paper was excluded. It was the case of "Knowledge evolution strategies and organizational performance: A strategic fit analysis". In this paper, Chen \& Liang (2011)had cited that used BSC but not bring explicated the 
financial performance indicators considered. In another way, if the paper did not use only KM or KMS practices as an independent variable, the paper was excluded. It was the case of "Enterprise Systems Adoption and Firm Performance in Europe: The Role of Innovation" (ZAND et al., 2010). In this paper, the authors focused on Enterprise Systems that, in their vision are "large-scale, integrated, cross-functional, and data-centric application software that provide service to all or a group of organizational subunits. Enterprise systems consist of different categories, such as Enterprise Resource Planning (ERP), Supply Chain Management (SCM), Customer Relationship Management (CRM), Knowledge Management System (KMS), and Document Management System (DMS)". Those cases were argued between authors and the result of this stage was that 44 papers were classified as relevant to this research. The list of them are in the Appendix A.

Finally, the classification into selected categories to financial performance and $\mathrm{km}$ practices, sometimes required an interpretation by the authors since the names found in the selected papers were not exactly the same in the categories. In those cases, consensus between authors was used.

These measures together give us a good degree of confidence that most of the relevant papers, have been identified, although there is a risk that some less influential papers have been missed. Therefore, this systematic review cannot guarantee completeness but can still be trusted to give a good overview of the relevant literature on the linking between KMS and financial performance.

\subsection{Data extraction}

The data extracted from each paper were maintained through the whole review process. After identification of the relevant papers, the following data were extracted: the source (journal or conference), title, authors, publication year, financial performance indicators, method, summary of the research (including which questions were solved) and findings Summary.

Based on the criteria for classifying the papers, all relevant papers were reviewed, and the corresponding data were extracted. It is not easy and, because of this, further criteria for classifying the papers were defined and discussed by the research team, based on what information was available in the papers. When needed, the categories were updated or clarified during the classification process.

\subsection{Data synthesis}

When there was any uncertainty about the classification of the studies, the issue was discussed by all authors until agreement was reached. The data synthesis was specified in the review protocol from the beginning of the systematic review. 


\section{Results}

Many topics were analised in the selected papers of this research. Firstly, KM practices found were categorized according to Ho (2009). Secondly, the financial indicators used were compared to indicators identified by Combs; Crook; Shook (2005). Thirdly, the most frequently measures used in the relationship between KM practices and financial performance were identified. Finally, we identified the most used methods to evaluate impact of $\mathrm{KM}$ in $\mathrm{FP}$, evaluation of number of Publications per year and evaluation of Authors, Publishers.

\subsection{KM practices}

Table 3 shows absolute and relative frequency of KM practices founded in selected papers and categorized according to Ho (2009). In total, it was found $161 \mathrm{KM}$ practices. Practices like "KM Process" are more linked with FP than practices of "KM Enabler or Infrastructure" in the selected papers $(60 \% \times 40 \%$ respectively). IT, Intellectual Capital, Acquisition and Culture are the main practices linked with organizational performance. In total, there are 12 practices more used among the 161 found.

Table 3 - absolute and relative frequency of KM practices -

\begin{tabular}{|c|c|c|c|c|c|c|c|c|}
\hline$\Xi$ KM Enabler or Infrastructure & 65 & $40 \%$ & KM Processes & 96 & $60 \%$ & KM Processes & Frequence & $\%$ \\
\hline IT & 13 & $8 \%$ & Acquistion & 14 & $9 \%$ & Implementation & 1 & $1 \%$ \\
\hline Intellectual Capital & 11 & $7 \%$ & Sharing & 9 & $6 \%$ & learning & 1 & $1 \%$ \\
\hline $\begin{array}{l}\text { Culture } \\
\text { Strategy }\end{array}$ & 10 & $\begin{array}{l}6 \% \\
4 \%\end{array}$ & Application & 6 & $4 \%$ & Internal Learning Process & 1 & $1 \%$ \\
\hline $\begin{array}{l}\text { Strategy } \\
\text { Organizational Structure }\end{array}$ & $\begin{array}{l}6 \\
4\end{array}$ & $\begin{array}{l}4 \% \\
2 \%\end{array}$ & Conversion & 5 & $3 \%$ & Disposal & 1 & $1 \%$ \\
\hline Leadership & 2 & $1 \%$ & Creation & 5 & $3 \%$ & Evaluation & 1 & $1 \%$ \\
\hline Responsiveness & 1 & $1 \%$ & Protection & 5 & $3 \%$ & Integration & 1 & $1 \%$ \\
\hline structure & 1 & $1 \%$ & Codification & 5 & $3 \%$ & Exchanging & 1 & $1 \%$ \\
\hline Social Capital & 1 & $1 \%$ & Utilization & 5 & $3 \%$ & Knowledge Embedding & 1 & $1 \%$ \\
\hline Extension of KMS & 1 & $1 \%$ & Transfer & 3 & $2 \%$ & Transformation & 1 & $1 \%$ \\
\hline Utilization & 1 & $1 \%$ & Trust & 2 & $1 \%$ & Knowledge Modification & 1 & $1 \%$ \\
\hline $\begin{array}{l}\text { Mechanisms and practices of KMS } \\
\text { Assets }\end{array}$ & $\begin{array}{l}1 \\
1\end{array}$ & $\begin{array}{l}1 \% \\
1 \%\end{array}$ & Human Capital & 2 & $1 \%$ & Conception & 1 & $1 \%$ \\
\hline Objective & 1 & $1 \%$ & Personalisation & 2 & $1 \%$ & Knowledge Translation & 1 & $1 \%$ \\
\hline Processors & 1 & $1 \%$ & Institutionalization & 2 & $1 \%$ & KM Implementation and Evaluation & 1 & $1 \%$ \\
\hline Tacit Knowledge & 1 & $1 \%$ & Internalization & 2 & $1 \%$ & Market orientation & 1 & $1 \%$ \\
\hline Processes & 1 & $1 \%$ & growth & 2 & $1 \%$ & organizational learning & 1 & $1 \%$ \\
\hline Explicit Knowledge & 1 & $1 \%$ & External Learning Process & 1 & $1 \%$ & Kevolution & 1 & $1 \%$ \\
\hline system-oriented strategy & 1 & $1 \%$ & Dissemination & 1 & $1 \%$ & Information Capital & 1 & $1 \%$ \\
\hline $\begin{array}{l}\text { Knowledge From Customer } \\
\text { Knowledge about Customer }\end{array}$ & $\begin{array}{l}1 \\
1\end{array}$ & $\begin{array}{l}1 \% \\
1 \%\end{array}$ & Archiving & 1 & $1 \%$ & K mutation & 1 & $1 \%$ \\
\hline Collaborative experience & 1 & $1 \%$ & Analytical capabilities & 1 & $1 \%$ & Adoption & 1 & $1 \%$ \\
\hline Knowledge for Customer & 1 & $1 \%$ & Responsiveness & 1 & $1 \%$ & accumulation & 1 & $1 \%$ \\
\hline Incentive & 1 & $1 \%$ & Kcrossover & 1 & $1 \%$ & Knowledge Disposal & 1 & $1 \%$ \\
\hline Size & 1 & $1 \%$ & & & & & & \\
\hline
\end{tabular}

Font: Research data.

\subsection{Financial Performance Indicators}

This research had analyzed the financial indicators used on the selected papers. In the 44 papers, it was found 165 events about financial indicators. There are 88 different indicators used in the selected papers from this research and 53 from the Comb's research. However, some indicators found by Combs; Crook; Shook (2005) were not found on this 
research. These 88 different indicators had categorized first in the "Organizational Performance Measures" or "Operational Performance Measures" categories according to Combs; Crook; Shook (2005).

To understand the most used indicators (or measures), we categorized the 88 measures in 32 from Combs; Crook; Shook (2005). The exact names of the indicators were, sometimes, not found. In these cases, an author's interpretation was considered: for example Economic Value Added (EVA) was categorized as "Organizational Performance Measure - Accounting returns" as a kind of "Profit scale". Tables 4 and 5 show the results about absolute and relative frequencies of organization and operational measures according to Comb's (2005) framework.

Table 4 - Absolute and relative frequency of indicators by group

\begin{tabular}{l|c|c|c|c}
\hline Group & Operational & Organizational & $\%$ by total & $\%$ by group \\
\hline \hline 1-Growth & & 31 & $19 \%$ & $27 \%$ \\
\hline 1-Accounting returns & & 70 & $42 \%$ & $61 \%$ \\
\hline 1-Stock market & & 9 & $5 \%$ & $8 \%$ \\
\hline 1-Hybrids & & 5 & $3 \%$ & $4 \%$ \\
\hline 2-Operations & 16 & & $10 \%$ & $32 \%$ \\
\hline 2-Marketing & 12 & & $1 \%$ & $24 \%$ \\
\hline 1-Stock market & 1 & & $8 \%$ & $2 \%$ \\
\hline 2-Service Quality & 13 & & $2 \%$ & $26 \%$ \\
\hline 2-Hybrids & 3 & & $2 \%$ & $6 \%$ \\
\hline 2-Technology development & 4 & & 115 & $2 \%$ \\
\hline 2-Infraestruture & 1 & & & \\
\hline Total (absolute frequency) & 50 & & & 2 \\
\hline
\end{tabular}

Font: Research data.

Table 4 shows that, considering both groups, "Accounting returns" has the bigger relative frequency (42\%), followed by "Operations" $(10 \%)$ and "Service Quality" (8\%). Table 5 shows a deeper analyse and look at the indicators. In this view, at the Organizational group, the indicators with bigger frequency are Profit scale, ROI and market share. At the operational group, service quality, costs/x and sales/x are the indicators with differentiated absolute frequency. 
Table 5 - Absolute and relative frequency of categorized measures

\begin{tabular}{|c|c|c|c|c|c|c|c|c|c|}
\hline \multicolumn{10}{|c|}{ Absolute and relative frequency of categorized indicators } \\
\hline Indicators by categorie & $\begin{array}{l}\text { Opera- } \\
\text { tional level }\end{array}$ & $\begin{array}{c}\text { Organi- } \\
\text { zational } \\
\text { level }\end{array}$ & $\begin{array}{l}\text { Abso-lute } \\
\text { freq }\end{array}$ & $\%$ & Indicators by categorie & Opera-tional level & $\begin{array}{c}\text { Organi- } \\
\text { zational level }\end{array}$ & $\begin{array}{c}\text { Abso-lute } \\
\text { freq }\end{array}$ & $\%$ \\
\hline 1-Accounting returns & & 70 & 70 & $42 \%$ & 2-Hybrids & 3 & & 3 & $2 \%$ \\
\hline Profit scale & & 32 & 32 & $19 \%$ & CAR (Cumulative Abnormal Return) & 1 & & 1 & $1 \%$ \\
\hline $\mathrm{ROI}$ & & 14 & 14 & $8 \%$ & Employee satisfaction & 1 & & 1 & $1 \%$ \\
\hline ROA & & 12 & 12 & $7 \%$ & Stock price / earnings & 1 & & 1 & $1 \%$ \\
\hline ROE & & 6 & 6 & $4 \%$ & 2-Infraestruture & 1 & & 1 & $1 \%$ \\
\hline cash flow / assets & & 3 & 3 & $2 \%$ & collaborative success scale & 1 & & 1 & $1 \%$ \\
\hline ROS & & 1 & 1 & $1 \%$ & 2-Marketing & 12 & & 12 & $7 \%$ \\
\hline net income & & 1 & 1 & $1 \%$ & Sales $/ \mathrm{x}$ & 6 & & 6 & $4 \%$ \\
\hline financial & & 1 & 1 & $1 \%$ & revenue & 4 & & 4 & $2 \%$ \\
\hline 1-Growth & & 31 & 31 & $19 \%$ & sales $/ x$ & 2 & & 2 & $1 \%$ \\
\hline market share & & 13 & 13 & $8 \%$ & 2-Operations & 16 & & 16 & $10 \%$ \\
\hline Growth scale & & 12 & 12 & $7 \%$ & $\operatorname{Cos} t x / x^{*}$ & 6 & & 6 & $4 \%$ \\
\hline Sales growth & & 6 & 6 & $4 \%$ & productivity & 3 & & 3 & $2 \%$ \\
\hline 1-Hybrids & & 5 & 5 & $3 \%$ & product quality scale & 2 & & 2 & $1 \%$ \\
\hline overall performance scale & & 4 & 4 & $2 \%$ & Cycle time & 2 & & 2 & $1 \%$ \\
\hline Stock price / earnings & & 1 & 1 & $1 \%$ & ocupancy/load rate & 1 & & 1 & $1 \%$ \\
\hline 1-Stock market & 1 & 9 & 10 & $6 \%$ & competitiveness & 1 & & 1 & $1 \%$ \\
\hline Tobin Q & & 7 & 7 & $4 \%$ & efficiency & 1 & & 1 & $1 \%$ \\
\hline \multirow[t]{5}{*}{ Security analyst assessments } & 1 & 2 & 3 & $2 \%$ & 2-Service Quality & 13 & & 13 & $8 \%$ \\
\hline & & & & & service quality & 11 & & 11 & $7 \%$ \\
\hline & & & & & customer satisfaction & 2 & & 2 & $1 \%$ \\
\hline & & & & & 2-Technology development & 4 & & 4 & $2 \%$ \\
\hline & & & & & Innovation scale & 4 & & 4 & $2 \%$ \\
\hline
\end{tabular}

Font: Research data.

\subsection{Relationship between KM practices and financial performance}

Considering the link between the 12 more used KM practices and the most used measures, it is possible to conclude that the bigger number of papers was associating profit scale with acquisition, culture, IT, sharing and utilization practices. Acquisition is also the most associated with the second and third bigger measure used - ROA and ROI.

Table 6 - Number of papers that link most used KM practices and financial measures

Font: Research data.

\begin{tabular}{|c|c|c|c|c|c|c|c|c|}
\hline \multirow[b]{2}{*}{ KM Practices } & \multicolumn{8}{|c|}{ Financial Performance Indicators } \\
\hline & $\begin{array}{l}\text { Costx } \\
/ \mathrm{x}\end{array}$ & $\begin{array}{l}\text { Growth } \\
\text { scale }\end{array}$ & $\begin{array}{c}\text { market } \\
\text { share }\end{array}$ & $\begin{array}{l}\text { Profit } \\
\text { scale }\end{array}$ & ROA & ROI & $\begin{array}{c}\text { Sales } \\
/ \mathbf{x}\end{array}$ & $\begin{array}{l}\text { service } \\
\text { quality }\end{array}$ \\
\hline \multicolumn{9}{|c|}{ KM Enabler or Infrastructure } \\
\hline Culture & 1 & 2 & 1 & 13 & 4 & 4 & & 2 \\
\hline Intellectual Capital & 1 & 1 & 4 & 4 & 3 & 2 & 4 & 1 \\
\hline Strategy & 1 & 2 & 3 & 5 & 1 & 1 & & \\
\hline Utilization & & & & 1 & & 1 & & \\
\hline IT & 1 & 2 & 1 & 12 & 6 & 6 & 2 & 3 \\
\hline \multicolumn{9}{|l|}{ KM Processes } \\
\hline Acquistion & 1 & 4 & 3 & 14 & 7 & 6 & 2 & 1 \\
\hline Application & 1 & 1 & & 5 & 3 & 1 & 1 & 2 \\
\hline Codification & & 3 & 2 & 4 & & 1 & 1 & 1 \\
\hline Conversion & & 1 & & 4 & 3 & 1 & 1 & \\
\hline Creation & 3 & 2 & & 9 & & 3 & & 4 \\
\hline Sharing & 2 & 4 & 4 & 10 & & 5 & 2 & 4 \\
\hline Utilization & 1 & 1 & & 8 & 2 & 4 & & \\
\hline
\end{tabular}

\subsection{Main methods used}

We focus on FP indicators instead of KM processes and practices. Main findings were also listed in order to provide an overview of results. We also study the methods used by authors to evaluate impact of KM in 
FP. $40 \%$ of authors use Structural equation Model (SEM), $7 \%$ use regression analysis and 7\% use multiple regression. Rest of articles uses different statistics methods like Matched Sample Comparison Group (MSCG), ANOVA, Bayesian network (BN) classifier, rough set theory (RST), Neural Network, SVM, Decision Tree.

\subsection{Evaluation of number of publications per year}

Evaluation of publications data according shows that number of publications is small but relatively continuous since 2010, with small variation.

Figure 3 - number of publications by year

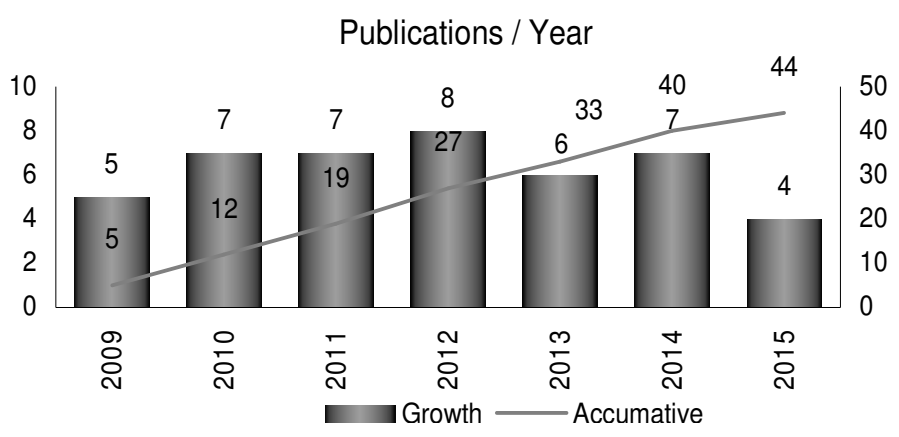

Font: Research data.

\subsection{Evaluation of authors, publishers}

Evaluation of authors data according to ideas created by Lotka (1926) known as "the inverse square law of scientific productivity" shows that only a small number of authors produces more than one document. In the set of papers selected at this search, just two authors Erickson, G. Scott and Rothberg, Helen N. published more than 1 document.

A frequency distribution analysis over words used in titles and keywords was evaluated. As expected, the most common words are knowledge, management and performance however with different orders: Knowledge, management and performance for titles and performance, knowledge, management for keywords.

Once the value proposition was analyze important words, prepositions and articles were removed, so we cannot verify first Zipf law. However we verify that words with low frequency got similar values of occurrence.

Nearly $51 \%$ of publishers are in his first paper related to $\mathrm{KM}$ and performance. In our research the 5 more active publishers are responsible for $40 \%$ of publications. Journal of Knowledge Management is the only publishers with more than 5 papers. 


\section{Conclusion}

The literature is full of studies about KM, most part of them suggest $\mathrm{KM}$ brings positive impact in organizational performance. However, fewer studies focus on financial performance, especially when we consider use of well-known financial indicators. Despite lack of confirming empirical evidence, it has been widely accepted in the KM literature have positive effect over financial results. This lack of confirmation arises in tough question about how to quantify KM gains. Different outcomes could be explained partially by different compositions of knowledge infrastructure and knowledge process, of course, financial indicators are also extremely sensitive to external factors such as new products, economic fluctuation and so on. Besides, during the analyses, we confirm the affirmative of Clyde W. Holsapple, Jiming Wu b (2011): most of the empirical findings are based on perceptions of independent and dependent variables by persons embedded in the firms being studied. This is a risk.

All search objectives are achieved at this work. It was possible to understand if $\mathrm{KM}$ practices and financial performance were correlated over last six years. Lotka (1926) and Zipf laws were used to understand a little bit about the authors and their publications. The main KM practices that had been linked with financial performance had become clear. A whole picture of financial indicators that had been more cited in the selected papers were presented and grouped according to Combs; Crook; Shook (2005).

This study contributes to the KM literature by going beyond case studies, providing a systemic review of the link between KMS and financial performance in the six last years. From that, 43 relevant articles are selected from two electronic databases and 1 added manually. This research shows that organizational performance had been measured, mainly, by accounting indicators like profit and ROI. However, is subject to some limitations, more databases could be added and also other specific search strings could be tested or a big period could be considered, as well evaluate financial performance for companies with KM maturity models.

We notice several methods tried to explain this relationship, including traditional approaches like statistics methods over surveys. But also new ones like correlation between public financial data and thirdparty awards for KM. The findings also suggest a number of avenues for future work, including proposal an overall evaluation method in order to be executed by practitioners and academics to create a huge database of works using same set of indicators for KM and for financial performance based on most common indicators found here.

\section{References}

AKHAVAN, P.; ELAHI, B.; JAFARI, M. A new integrated knowledge model in supplier selection: the case of an Asian automotive supply chain. 
Education, Business and Society: Contemporary Middle Eastern Issues, v. 7, n. 4, p. 333-368, 2014. Available at: <http://doi.org/10.1108/EBS-072014-0035>. Accessed: 20 Sept. 2015.

ALAVI, M.; LEIDNER, D. E. Knowledge management and knowledge management systems: conceptual foundations and research issues. MIS Quarterly, v. 25, n. 1, p. 107-136, 2001. Available at: <http://www.jstor.org/stable/3250961> Accessed: 20 Sept. 2015.

ANDERSEN, A. The KMAT: Benchmarking knowledge management. Arthur Andersern Business Consulting, 1999. p. 1-6, Available at: $<$ http://iatul.org/doclibrary/public/Conf

Proceedings/1998/THEKMATdeJager.doc>. Accessed: 20 Sept. 2015.

ANDREEVA, T.; KIANTO, A. Does knowledge management really matter? Linking knowledge management practices, competitiveness and economic performance. Journal of Knowledge Management, v. 16, n. 4, p. 617-636, 2012. Available at: <http://doi.org/10.1108/13673271211246185>. Accessed: 20 Sept. 2015.

ASIAEI, K.; JUSOH, R. A multidimensional view of intellectual capital: The impact on organizational performance. Management Decision, v. 53, n. 3, p. 668-697, 2015. Available at: <http://doi.org/10.1108/MD-05-20140300>. Accessed: 20 Sept. 2015.

BANFF, A.; BAPUJI, H. Firm performance: a multidimensional operationalization. 2006. Available at: <http://libra.acadiau.ca/library/ASAC/v27/content/division/strategy/fullpr oceedings.pdf\#page $=166>$. Accessed: 20 Sept. 2015 .

CHAREONSUK, C.; CHANSA-NGAVEJ, C. Intangible asset management framework for long-term financial performance. Industrial Management and Data Systems, v. 108, n. 6, p. 812-828, 2008. ISSN 02635577. Available at: <http://doi.org/10.1108/02635570810884021>. Accessed: 20 Sept. 2015.

CHEN, C.-J. et al. Intellectual capital and new product development. Journal of Engineering and Technology Management, v. 33, p. 154-173, 2014. ISSN 0923-4748. Available at: <http://dx.doi.org/10.1016/j.jengtecman.2014.06.003>. Accessed: 20 Sept. 2015.

CHEN, D.-N.; LIANG, T.-P. Knowledge evolution strategies and organizational performance: a strategic fit analysis. Electronic Commerce Research and Applications, v. 10, n. 1, p. 75 - 84, 2011. ISSN 1567-4223. Available at: <http://dx.doi.org/10.1016/j.elerap.2010.10.004>. Accessed: 20 Sept. 2015.

CHEN, M.-Y.; CHEN, A.-P. Knowledge management performance evaluation: a decade review from 1995 to 2004. Journal of Information Science, v. 32, n. 1, p. 17 - 38, 2006. ISSN 01655515. Available at: 
<http://jis.sagepub.com/content/32/1/17.short>. Accessed: 20 Sept. 2015.

CHEN, M.-Y.; HUANG, M.-J.; CHENG, Y.-C. Measuring knowledge management performance using a competitive perspective: an empirical study. Expert Systems with Applications, v. 36, n. 4, p. 8449 - 8459, 2009. ISSN 0957-4174. Available at: <http://dx.doi.org/10.1016/j.eswa.2008.10.067>. Accessed: 20 Sept. 2015.

CHOI, B.; JONG, A. M. Assessing the impact of knowledge management strategies announcements on the market value of firms. Information \& Management, v. 47, n. 1, p. 42-52, 2010. ISSN 0378-7206. <Available at: http://dx.doi.org/10.1016/j.im.2009.10.001>. Accessed: 20 Sept. 2015.

CHUANG, S.-H.; LIAO, C.; LIN, S. Determinants of knowledge management with information technology support impact on firm performance. Information Technology and Management, v. 14, n. 3, p. 217-230, 2013. ISSN 1385951X. Available at: <http://doi.org/10.1007/s10799-013-0153-1>. Accessed: 20 Sept. 2015.

COHEN, J. F.; OLSEN, K. Knowledge management capabilities and firm performance: a test of universalistic, contingency and complementarity perspectives. Expert Systems with Applications, v. 42, n. 3, p. 1178 1188, 2015. ISSN 0957-4174. Available at: <http://doi.org/10.1016/j.eswa.2014.09.002>. Accessed: 20 Sept. 2015.

DAVENPORT, T. H.; PRUSAK, L. Working knowledge: how organizations manage what they know. Boston, MA: Harvard Business Press, 1998. Available at: <https://books.google.com.br/books?hl=pt-BR\&lr=\&id=-47vmCVG5cC\&oi=fnd\&pg $=$ PR7\&dq =Working+Knowledge: +How+Organizati ons+Manage+What+They+Know+By+Thomas+H.+Davenport+and+Lawr ence+Prusak.\&ots $=$ myidZXbjL8\&sig $=$ EdoNPiE22A1 hI52X4ynOKfoqDtk $>$.

Accessed: 20 Sept. 2015.

DEFOND, M. L. et al. Capital markets valuation and accounting performance of Most Admired Knowledge Enterprise (MAKE) award winners. Decision Support Systems, v. 56, p. 348 - 360, 2013. ISSN 01679236. Available at: <http://dx.doi.org/10.1016/j.dss.2013.07.001>. Accessed: 20 Sept. 2015.

DELEN, D. et al. A comparative analysis of machine learning systems for measuring the impact of knowledge management practices. Decision Support Systems, v. 54, n. 2, p. 1150-1160, 2013. ISSN 0167-9236. Available at: <http://dx.doi.org/10.1016/j.dss.2012.10.040>. Accessed: 20 Sept. 2015.

ERICKSON, G. S.; ROTHBERG, H. N. Intellectual capital in business-tobusiness markets. Industrial Marketing Management, v. 38, n. 2, p. 159165, 2009. ISSN 0019-8501. Available at: <http://dx.doi.org/10.1016/j.indmarman.2008.12.001>. Accessed: 20 Sept. 2015. 
ERICKSON, G. S.; ROTHBERG, H. N. Knowledge assets in services across industries and across time. Investigaciones Europeas de Dirección $Y$ Economía de La Empresa, v. 21, n. 2, p. 58-64, 2015. ISSN 1135-2523. Available at: <http://dx.doi.org/10.1016/j.iedee.2014.09.002>. Accessed: 20 Sept. 2015.

HAO, Q.; KASPER, H.; MUEHLBACHER, J. How does organizational structure influence performance through learning and innovation in Austria and China. Chinese Management Studies, v. 6, n. 1, p. 36 - 52, 2012. ISSN 1750614X. Available at: <http://doi.org/10.1108/17506141211213717>. Accessed: 20 Sept. 2015.

HEDMAN, J.; KALLING, T. The business model concept: theoretical underpinnings and empirical illustrations. European journal of information systems, v. 12, n. 1, p. 49 59, 2003. Available at: <http://www.palgravejournals.com/ejis/journal/v12/n1/abs/3000446a.html>. Accessed: 20 Sept. 2015.

$\mathrm{HO}$, C.-T. The relationship between knowledge management enablers and performance. Industrial Management and Data Systems, v. 109, n. 1, p. 98-117, 2009. ISSN 02635577. Available at: <http://doi.org/10.1108/02635570910926618> (accessed 20.09.2015.)

HOLSAPPLE, C. W.; WU, J. An elusive antecedent of superior firm performance: the knowledge management factor. Decision Support Systems, v. 52, n. 1, p. 271-283, 2011. ISSN 0167-9236. Available at: <http://dx.doi.org/10.1016/j.dss.2011.08.003>. Accessed: 20 Sept. 2015.

HSU, I.-C.; SABHERWAL, R. Relationship between intellectual capital and knowledge management: an empirical investigation. Decision Sciences, v. 43, n. 3, p. 489 - 524, 2012. ISSN 00117315. Available at: <http://doi.org/10.1111/j.1540-5915.2012.00357.x>. Accessed: 20 Sept. 2015.

HU, Y. The impact of market orientation on knowledge management: an empirical investigation in china. In: INTERNATIONAL CONFERENCE ON KNOWLEDGE DISCOVERY AND DATA MINING, 3., WKDD 2010. Proceedings... 2010. p. 432 435. ISBN 978-0-7695-3923-2. Phuket. Available at: <http://doi.org/10.1109/WKDD.2010.97>. Accessed: 20 Sept. 2015.

JOSHI, H.; CHAWLA, D.; FAROOQUIE, J. Segmenting knowledge management (KM) practitioners and its relationship to performance variation some empirical evidence. Journal of Knowledge Management, v. 18, n. 3, p. 469-493, 2014. ISSN 13673270. Available at: <http://doi.org/10.1108/JKM-10-2013-0380>. Accessed: 20 Sept. 2015.

KAMYA, M.; NTAYI, J.; AHIAUZU, A. Organisational learning and competitive advantage: Testing for the interacting inuence of knowledge management and innovation. International Journal of Innovation and Learning, v. 10, n. 4, p. 376 - 401, 2011. ISSN 14718197. Available at: <http://doi.org/10.1504/IJIL.2011.043097>. Accessed: 20 Sept. 2015. 
KAPLAN, R. S.; NORTON, D. P. Using the balanced scorecard as a strategic management system. Boston, MA: Harvard Business Review, 1996. Available at: <https://noppa.tkk.fi/noppa/kurssi/tu-22.1500/luennot/TU-22_1500_prereading_1_kaplan__norton_1996_.pdf>. Accessed: 20.09.2015.

KARJALAINEN, J.; VALTAKOSKI, A. On the role of partners in a multi-disciplinary business network: a knowledge management perspective. In: ANNUAL HAWAII INTERNATIONAL CONFERENCE ON SYSTEM SCIENCES. [s.n.], 2010. Proceedings... 2010. ISBN 978-0-7695-3869-3. Available at: <http://doi.org/10.1109/HICSS.2010.466>. Accessed: 20 Sept. 2015.

KIANTO, A. et al. The impact of knowledge management practices on organizational performance. In: EUROPEAN CONFERENCE ON KNOWLEDGE MANAGEMENT, ECKM. [s.n.], 2013. Proceedings... 2013. v. 1, p. 356 - 361. ISBN 978-1-62993-1401. Kaunas. Available at: <http://www.scopus.com/inward/record.url?eid=2-s2.084893553690\&partnerID =40\&md5 =b1cd322ab87be2b31709224b9ea33a 5d>. Accessed: 20 Sept. 2015.

KITCHENHAM, B. Procedures for performing systematic reviews. Keele, UK, Keele University, v. 33, n. 2004, p.1 - 26, 2004. Available at: <http://testszingarelli.googlecode.com/svn-history/r336/trunk/2-Artigos-

Projeto/Revisao-Sistematica/Kitchenham-Systematic-Review-2004.pdf> . Accessed: 20 Sept. 2015.

LIAO, Y.-S. The effect of human resource management control systems on the relationship between knowledge management strategy and firm performance. International Journal of Manpower, v. 32, n. 5, p. 494-511, 2011. ISSN 01437720. Available at: <http://doi.org/10.1108/01437721111158170>. Accessed: 20 Sept. 2015.

LIN, H.-F. A multi-stage analysis of antecedents and consequences of knowledge management evolution. Journal of Knowledge Management, v. 18, n. 1, p. 52 - 74, 2014. ISSN 13673270. Available at: <http://doi.org/10.1108/JKM-07-20130278>. Accessed: 20 Sept. 2015.

LÓPEZ-NICOLÁS, C.; MEROÑO-CERDÁN, Á. L. Strategic knowledge management, innovation and performance. International Journal of Information Management. v. 31, n. 6, p. 502-509, 2011. ISSN 0268-4012. Available at: <http://dx.doi.org/10.1016/j.ijinfomgt.2011.02.003>. Accessed: 20 Sept. 2015.

MANZANARES, M. J. D.; GÓMEZ, F. G. Estrategia de gestión del conocimiento y actitud innovadora en empresas de Castilla-La Mancha. Un estudio exploratorio. Investigaciones Europeas de Dirección Y Economía de La Empresa, v. 16, n. 1, p. 31-54, 2010. ISSN 1135-2523. Available at: <http://dx.doi.org/10.1016/S1135-2523(12)60002-1>. Accessed: 20 Sept. 2015.

MEHRALIAN, G. E. et al. The impact of intellectual capital efficiency on market value: An empirical study from Iranian pharmaceutical companies. Iranian Journal of Pharmaceutical Research. v. 11, n. 1, p. 195-207, 2012. ISSN 17350328. 
<http://papers.ssrn.com/sol3/papers.cfm?abstract_id=2187799>. Accessed: 20 Sept. 2015.

MILLS, A. M.; SMITH, T. A. Knowledge management and organizational performance: A decomposed view. Journal of Knowledge Management, v. 15 , n. 1, p. 156-171, 2011. ISSN 13673270. Available at: <http://doi.org/10.1108/13673271111108756>. Accessed: 20 Sept. 2015.

MIRANDA, S. M.; LEE, J.-N.; LEE, J.-H. Stocks and flows underlying organizations' knowledge management capability: Synergistic versus contingent complementarities over time. Information \& Management, v. 48, n. 8, p. 382-392, 2011. ISSN 0378-7206. Available at: <http://dx.doi.org/10.1016/j.im.2011.10.002>. Accessed: 20 Sept. 2015.

NEELY, A. Business performance measurement: theory and practice. London, UK: Cambridge University Press, 2002. Available at: <https://books.google.com.br/books?hl=en\&lr=\&id=1KIEoQYx5ewC\&oi=f nd\&pg $=$ PR9\&dq =Neely,+ A. $+(2002) .+$ Business +Performance+Measureme nt: +Theory+and+Practice. +Cambridge: +Cambridge+University+Press\&ot

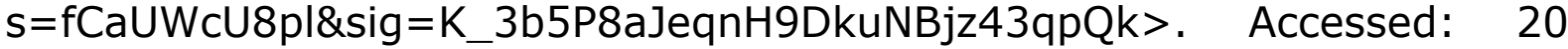
Sept. 2015.

NEELY, A.; GREGORY, M.; PLATTS, K. Performance measurement system design: a literature review and research agenda. International Journal of Operations \& Production Management, v. 15, n. 4, p. 80-116, 1995. Available at:

<http://www.emeraldinsight.com/doi/full/10.1108/01443570510633639> . Accessed: 20 Sept. 2015.

NOLD III, H. A. B. Linking knowledge processes with firm performance: organizational culture. Journal of Intellectual Capital, v. 13, n. 1, p. 16-38, 2012. ISSN 14691930. Available at: <http://doi.org/10.1108/14691931211196196>. Accessed: 20 Sept. 2015.

PÉREZ-LÓPEZ, S.; ALEGRE, J. Information technology competency, knowledge processes and firm performance. Industrial Management and Data Systems, v. 112, n. 4, p. 644-662, 2012. ISSN 02635577. Available at: <http://doi.org/10.1108/02635571211225521>. Accessed: 20 Sept. 2015.

RAO, Y.; GUO, K. H.; CHEN, Y. Information systems maturity, knowledge sharing, and firm performance. International Journal of Accounting and Information Management, v. 23, n. 2, p. 106-127, 2014. ISSN 18347649. Available at: <http://doi.org/10.1108/IJAIM-11-2013-0060>. Accessed: 20 Sept. 2015.

ROBLEK, V.; et al. The impact of social media to value added in knowledge-based industries. Kybernetes, v. 42, n. 4, p. 554-568, 2013. ISSN 0368492X. Available at: <http://doi.org/10.1108/K-01-2013-0014> (accessed 20.09.2015.) 
SCHOENHERR, T.; GRIFFITH, D. A.; CHANDRA, A. Knowledge management in supply chains: the role of explicit and tacit knowledge. Journal of Business Logistics, v. 35, n. 2, p. 121-135, 2014. ISSN 07353766. Available at: <http://doi.org/10.1111/jbl.12042>. Accessed: 20 Sept. 2015.

COMBS, J. G.; CROOK, T. R.; SHOOK, C. L. The dimensionality of organizational performance and its implications for strategic management research. Research Methodology in Strategy and Management, v. 2, n. 5, p. 259286 2 2005.2 Available at: <http://www.emeraldinsight.com/doi/abs/10.1016/S1479-8387(05)02011-4>.

Accessed: 20 Sept. 2015.

SIVARAMAKRISHNAN, S. et al. Critical success factors and outcomes of market knowledge management: a conceptual model and empirical evidence. International Journal of Knowledge Management, v. 6, n. 3, p. 121, 2010. ISSN 15480666. Available at: <http://doi.org/10.4018/jkm.2010070101>. Accessed: 20 Sept. 2015.

SLAVKOVIĆ, M.; BABIĆ, V. Knowledge management, innovativeness, and organizational performance: evidence from Serbia. Economic Annals, v. 58, n. 199, p. 85-108, 2013. ISSN 00133264. Available at: <http://doi.org/10.2298/EKA1399085S>. Accessed: 20 Sept. 2015.

SUGHEIR, J.; PHAN, P. H.; HASAN, I. Diversification and innovation revisited: An absorptive capacity view of technological knowledge creation. IEEE Transactions on Engineering Management, v. 59, n. 4, p. 530539, 2012. ISSN 00189391. Available at: <http://doi.org/10.1109/TEM.2011.2165726>. Accessed: 20 Sept. 2015.

TABRIZI, R. S.; EBRAHIMI, N.; AL-MARWAI, S. A. On the comparison of KM criteria classifications. Procedia Computer Science, v. 3, p. 684-690, 2011. <http://www.sciencedirect.com/science/article/pii/S1877050910004898>. Accessed: 20 Sept. 2015.

TUBIGI, M.; ALSHAWI, S. The impact of knowledge management processes on organisational performance: The case of the airline industry. Journal of Enterprise Information Management, v. 28, n. 2, p. 267-285, 2015. ISSN 17410398. Available at: <http://doi.org/10.1108/JEIM-01-20140003>. Accessed: 20 Sept. 2015.

VACCARO, A.; PARENTE, R.; VELOSO, F. M. Knowledge Management Tools, Inter-Organizational Relationships, Innovation and Firm Performance. Technological Forecasting and Social Change, v. 77, n. 7, p. 1076 - 1089, 2010. ISSN 0040-1625. Available at: <http://dx.doi.org/10.1016/j.techfore.2010.02.006>. Accessed: 20 Sept. 2015.

WANG, Z.; WANG, N. Knowledge sharing, innovation and firm performance. Expert Systems with Applications, v. 39, n. 10, p. 8899 - 8908, 2012.

ISSN

0957-4174.

Available

at: 
<http://dx.doi.org/10.1016/j.eswa.2012.02.017>. Accessed: 20 Sept. 2015.

WU, I.-L.; CHEN, J.-L. A stage-based diffusion of $\{$ IT $\}$ innovation and the \{BSC\} performance impact: A moderator of technology-organizationenvironment. Technological Forecasting and Social Change, v. 88, n. 0, p. 76- 2014. ISSN 0040-1625. Available at: <http://dx.doi.org/10.1016/j.techfore.2014.06.015>. Accessed: 20 Sept. 2015.

YANG, C.-C.; MARLOW, P. B.; LU, C.-S. Knowledge management enablers in liner shipping. Transportation Research Part E: Logistics and Transportation Review, v. 45, n. 6, p. 893 - 903, 2009. ISSN 1366-5545. Available at: <http://dx.doi.org/10.1016/j.tre.2009.05.003>. Accessed: 20 Sept. 2015.

ZACK, M.; MCKEEN, J.; SINGH, S. Knowledge management and organizational performance: an exploratory analysis. Journal of Knowledge Management, v. 13, n. 6, p. 392 - 409, 2009. Available at: <http://www.emeraldinsight.com/doi/abs/10.1108/13673270910997088 >. Accessed: 20 Sept. 2015.

ZAND, F.; et al. Enterprise Systems Adoption and Firm Performance in Europe: the Role of Innovation. In: AMERICAS CONFERENCE ON INFORMATION SYSTEMS 2010, 16., AMCIS 2010. Proceedings... 2010. v. 7, p. 5369-5386. ISBN 978-1-61738-952-8. Available at: <http://core.ac.uk/download/pdf/6614276.pdf>. Accessed: 20 Sept. 2015.

\section{APPENDIX A - List of Analyzed Papers}

Paper
Intellectual capital and new product development
Knowledge evolution strategies and organizational
performance: A strategic fit analysis
Measuring knowledge management performance using a
competitive perspective: An empirical study
Assessing the impact of knowledge management strategies
announcements on the market value of firms
Knowledge management capabilities and firm performance:
A test of universalistic, contingency and complementarity
perspectives
Capital markets valuation and accounting performance of
Most Admired Knowledge Enterprise (MAKE) award
winners
A comparative analysis of machine learning systems for
measuring the impact of knowledge management practices
Intellectual capital in business-to-business markets
Knowledge assets in services across industries and across
time

\section{Reference}

(C.-J. Chen, Liu, Chu, \&

Hsiao, 2014)

(D.-N. Chen \& Liang,

2011)

(M.-Y. Chen et al.,

2009)

(Choi \& Jong, 2010)

(Cohen \& Olsen, 2015)

\begin{tabular}{|c|c|c|c|c|c|c|}
\hline $\begin{array}{l}\text { ㅇ } \\
\text { 유 }\end{array}$ & 옹 & $\frac{\pi}{8}$ & $\frac{\mathbf{N}}{\mathbf{N}}$ & $\frac{m}{\stackrel{\Gamma}{\Gamma}}$ & $\frac{ \pm}{8}$ & $\frac{10}{\frac{0}{0}}$ \\
\hline
\end{tabular}

1

(DeFond, Konchitchki, McMullin, \& O'Leary,

2013)

(Delen, Zaim, Kuzey, \&

Zaim, 2013)

(Erickson \& Rothberg, 2009)

(Erickson \& Rothberg,

2015) 
Knowledge Management System and Financial Performance: how this relation has been measured? Magalhães Castro; Fabricio Ziviani; Fernando Silva Parreiras
An elusive antecedent of superior firm performance: The knowledge management factor

Strategic knowledge management, innovation and performance

ESTRATEGIA DE GESTION DEL CONOCIMIENTO Y ACTITUD INNOVADORA EN EMPRESAS DE CASTILLALA MANCHA. UN ESTUDIO EXPLORATORIO

Stocks and flows underlying organizations' knowledge management capability: Synergistic versus contingent complementarities over time

Paper

Knowledge Management Tools, Inter-Organizational Relationships, Innovation and Firm Performance

Knowledge sharing, innovation and firm performance A stage-based diffusion of IT innovation and the BSC performance impact: A moderator of technologyorganization-environment

Knowledge management enablers in liner shipping

Knowledge management and organizational performance: an exploratory analysis

A new integrated knowledge model in supplier selection: The case of an Asian automotive supply chain

Does knowledge management really matter? Linking knowledge management practices, competitiveness and economic performance

A multidimensional view of intellectual capital: The impact on organizational performance

Intangible asset management framework: An empirical evidence

Determinants of knowledge management with information technology support impact on firm performance

How does organizational structure influence performance through learning and innovation in Austria and China

The relationship between knowledge management enablers and performance

Relationship between Intellectual Capital and Knowledge Management: An Empirical Investigation

The impact of market orientation on knowledge management: An empirical investigation in China

Segmenting knowledge management (KM) practitioners and its relationship to performance variation - Some empirical evidence

\section{Paper}

Organisational learning and competitive advantage:

Testing for the interacting influence of knowledge management and innovation

On the role of partners in a multi-disciplinary business network: A knowledge management perspective

The impact of knowledge management practices on organizational performance

The effect of human resource management control systems on the relationship between knowledge management strategy and firm performance
(Holsapple \& Wu, 2011)

(López-Nicolás \&

Meroño-Cerdán, 2011)

(Manzanares \& Gómez,

2010)

(Miranda, Lee, \& Lee, 2011)

Reference

\begin{tabular}{|c|c|c|c|c|c|}
\hline 옹 응 & స్ & $\stackrel{N}{\sim}$ & $\stackrel{m}{\infty}$ & $\stackrel{+}{D}$ & $\stackrel{n}{\stackrel{2}{N}}$ \\
\hline
\end{tabular}

(Vaccaro, Parente, \&

Veloso, 2010)

(Wang \& Wang, 2012)

(Wu \& Chen, 2014)

(Yang et al., 2009)

(Zack et al., 2009)

1

(Akhavan, Elahi, \&

Jafari, 2014)

(Andreeva \& Kianto,

2012)

(Asiaei \& Jusoh, 2015)

(Chareonsuk \&

Chansa-Ngavej, 2008)

(Chuang, Liao, \& Lin,

2013)

(Hao, Kasper, \&

Muehlbacher, 2012)

(Ho, 2009)

(Hsu \& Sabherwal, 2012)

(Hu, 2010)

(Joshi et al., 2014)

Reference

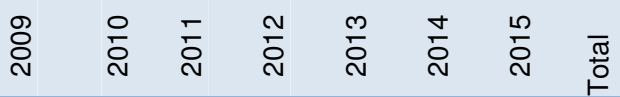

(Kamya, Ntayi, \&

Ahiauzu, 2011)

(Karjalainen \&

Valtakoski, 2010)

(Kianto, Ritala,

Vanhala, \& Inkinen,

2013)

(Liao, 2011) (1) (1) 
Knowledge Management System and Financial Performance: how this relation has been measured?

Fabiana Dutra de Campos Souza; Djan Magalhães Castro; Fabricio Ziviani; Fernando Silva Parreiras

A multi-stage analysis of antecedents and consequences of knowledge management evolution

The impact of intellectual capital efficiency on market value: An empirical study from Iranian pharmaceutical companies

Knowledge management and organizational performance: A decomposed view

Linking knowledge processes with firm performance:

Organizational culture

Information technology competency, knowledge processes and firm performance

Information systems maturity, knowledge sharing, and firm performance

The impact of social media to value added in knowledgebased industries

Knowledge management in supply chains: The role of explicit and tacit knowledge

Critical success factors and outcomes of market knowledge management: A conceptual model and empirical evidence

Knowledge management, innovativeness, and organizational performance: Evidence from Serbia

Paper

Diversification and innovation revisited: An absorptive capacity view of technological knowledge creation

The impact of knowledge management processes on organisational performance: The case of the airline industry
(Lin, 2014)

(Mehralian, Rasekh,

Akhavan, \& Sadeh, 2012)

(Mills \& Smith, 2011)

(Nold III, 2012)

(Pérez-López \& Alegre,

2012)

(Rao, Guo, \& Chen,

2014)

(Roblek, Bach, Meško, \& Bertoncelj, 2013)

(Schoenherr, Griffith, \&

Chandra, 2014)

(Sivaramakrishnan, Delbaere, Zhang, \& Bruning, 2010) 2013)

Reference

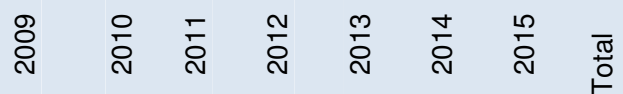

(Sugheir, Phan, \& Hasan, 2012)

(Tubigi \& Alshawi, 2015)
(Slavković \& Babić 